\title{
Identification and classification of resource-based cities in China
}

\author{
YU Jianhui ${ }^{1,2}$, "LI Jiaming ${ }^{1,2}$, ZHANG Wenzhong $^{1,2}$ \\ 1. Key Laboratory of Regional Sustainable Development Modeling, Institute of Geographic Sciences and Nat- \\ ural Resources Research, CAS, Beijing 100101, China; \\ 2. University of Chinese Academy of Sciences, Beijing 100049, China
}

\begin{abstract}
Resource-dependent cities are cities whose economic development depends on the exploitation and processing of natural resources. Their transformation and sustainable development are an important area of research on regional industrial development, regional economy and urban development. Since the Chinese government launched a pilot project to transform resource-dependent cities, starting with Fuxin in Liaoning Province in 2001, accurately identifying and classifying China's resource-dependent cities has become a focus of geographical research. Based on previous studies, this paper uses the theory and methods of urban function classification to analyze indicators and threshold values for identifying and classifying resource-dependent cities. It has thus identified 262 cities as being resource-dependent. Looking at the development levels, problems, characteristics and developmental direction of such cities, this paper attempts to establish a comprehensive analytical framework using the two evaluation indicators of resource security and sustainable development. It also creates a model to classify the 262 cities identified as resource-dependent cities into four types: growing cities, mature cities, declining cities and regenerating cities. The different connotations and characteristics of the city types were then analyzed. The results of this research support the delineation of scopes and categories of resource-dependent cities set out in the National Sustainable Development Plan for Resource-Dependent Cities published by the State Council, and they serve as a foundation for formulating policies on planning, classification and guidance.
\end{abstract}

Keywords: resource-dependent cities; identification; classification

\section{Introduction}

Resource-dependent cities are cities in which mining, forestry or other industries based on natural resources are the dominant industries. There are many resource-dependent cities across the country that have made enormous historical contributions and are of great importance within China. Since the founding of the People's Republic of China in 1949, re-

Received: 2018-09-17 Accepted: 2018-12-20

Foundation: National Natural Science Foundation of China, No.41671166, No.41701128

Author: Yu Jianhui (1983-), PhD and Associate Professor, specialized in resource-based cities development studies. E-mail: yujh@igsnrr.ac.cn

"Corresponding author: Li Jiaming (1984-), PhD and Associate Professor, E-mail: lijm.12b@igsnrr.ac.cn 
source-dependent cities have cumulatively produced 52.9 billion tons of raw coal, 5.5 billion tons of crude oil, 5.8 billion tons of iron ore, and 2 billion $\mathrm{m}^{3}$ of lumber. Of the 156 national key construction projects in the First Five-Year Plan for National Economic and Social Development of the People's Republic of China (1953-1957), 53 were located in resource-dependent cities and accounted for nearly half of all investment. They therefore played a unique role in helping to set up an independent and complete industrial system in China and boosting national economic development.

Nowadays, however, there is greater international political and economic uncertainty and instability, and issues such as unbalanced, uncoordinated and unsustainable national economic development have come to the fore. These, added to various internal and external factors, have created a patchwork of old and new issues that mean there are severe challenges to the sustainable development of resource-dependent cities. Correctly identifying and analyzing the various features of resource-dependent cities has thus become a prerequisite for deepening research on them and making relevant policies more targeted.

Accurately identifying resource-dependent cities is the first step in analyzing their features and problems. Although the term resource-dependent city is widely used, there are no unified criteria for identifying such cities among governments and scholars in China, resulting in a variety of methods of identification. Methods of identification of scholars range from qualitative to quantitative and can involve single or multiple indicators. Early researchers tended to identify mining cities by the proportion of workers employed by mining industries (Harris, 1943), with indicative threshold values such as 15\% (Ma, 1986; Shen and Cheng, 1999) or $10 \%$. Nelson's statistical analysis method differentiated urban functions based on the arithmetic mean (M) and standard deviation (S) of employment in cities (Nelson, 1955). On the basis of these studies, Zhou Yixing et al. used a combination of multiple factor analysis and statistical analysis to differentiate the functions of Chinese cities (Zhou and Roy, 1988; Zhou and Sun, 1997). Wu and Ye (2000) considered the connectivity of industries and set the identification standard for resource-dependent cities as those with over $40 \%$ of their labor force employed in resource extraction and preliminary processing of resources. Other scholars tend to identify resource-dependent cities by the proportion of their economic output accounted for by industrial output. Fan Jie (1993), Zhou Changqing (1994) and Zhang Yicheng (1999), for example, all identify resource-dependent cities as those with $10 \%$ or more of total economic output accounted for by mining industries, though Zhao Yukong (1995) feels that the standard should be set at $20 \%$. On the basis of efforts to identify resource-dependent cities using a single indicator, a number of studies have looked at using multiple indicators. Li Wenyan (1978), for instance, selected the following four indicators: coal mine workers accounting for over $25 \%$ of total urban workers, coal accounting for not less than $15 \%$ of urban industrial output, coal production in excess of 2 million tons per year, and coal mining being the main reason for the city's development. Other scholars have defined resource-dependent cities by combining the number and proportion of workers employed in extractive industries with the scale and proportion of industrial output of extractive industries (Wang, 2003; Yu and Liu, 2009). Following these studies, Hu Kui (2001) and the Chinese Mining Association's Working Committee of Mining Cities added qualitative indicators to include old mining cities where traditional mining functions still play an important role as well as new mining cities. Zhang and Wang (2003) proposed the concept of 
“dependence on mining" and defined resource-dependent cities using the weighted results of proportions of mining population and mining output value.

There are many resource-dependent cities in China at different stages of resource development. Their levels of economic and social development vary considerably, and they face myriad and often dissimilar problems. To properly understand the situations of resource-dependent cities, it is necessary to classify and differentiate target cities. Previous attempts at classifying resource-dependent cities have tended to involve the basic method of identifying the main type of resource affecting a city's economic and social development (MRGNPC, 2002; Xiao and Li, 2009). Liu Yungang (2006; 2009), for example, came up with five urban function classifications for resource-dependent cities based on types of resources: coal, petroleum, metal, non-metal and forestry, which were used to discuss the various tendencies of different cities in their evolution. Based on the S-shaped curve of development in resource-dependent cities, such cities were classified as being in their infancy, middle age or old age.

In general, though, a history of large-scale industrial mining and mining intensity are used as the standards for calculating which stage a city is in. Han and Wan (2014) proceeded from the lifecycle of resource-dependent cities and used reserve and production ratios, changes in the scale of extractive industries or resource-related industries, changes in employment levels and other indicators to divide cities into early-stage, mature and depleted resource-dependent cities. Other scholars have classified cities based on their dependence on resource extraction activities into lightly, mildly and heavily dependent cities (Zhao and Zhao, 2011). These traditional classification methods of differentiating by dominant resource type or urban development cycle highlight certain features of resource- dependent cities. However, these classifications still lack sufficient accuracy for policymaking.

In 2013, the State Council promulgated the National Sustainable Development Plan for Resource-Dependent Cities (hereinafter "Resource-Dependent Cities Plan"), which systematically laid out tasks for resource-dependent cities to achieve sustainable development over a period of time, including first identifying their number and scope and classifying them. As preliminary research connected to the Resource-Dependent Cities Plan, this study focuses on indicators and threshold values for identifying China's resource-dependent cities and discusses a comprehensive classification framework. It also analyzes the identification and classification of the 262 cities in the Resource-Dependent Cities Plan (Figure 1).

\section{Identifying resource-dependent cities}

The key to identifying resource-dependent cities is differentiating urban functions. Judging from the definition of resource-dependent cities given above, such cities have several basic features: first, they have an importance that corresponds to remarkable achievements in basic urban functions, mainly the external roles played by people (extractive industrial workers) and goods (resource products), which is measured by such indicators as specialization and level of resource output of extractive industries; second, they make huge contributions, either historical or potential (i.e. they have made or will make a significant contribution to national resource requirements over an extended period). Based on the foregoing, resource-dependent cities can be identified using three indicators: extraction function intensity, output coefficient and level of resource contribution. 


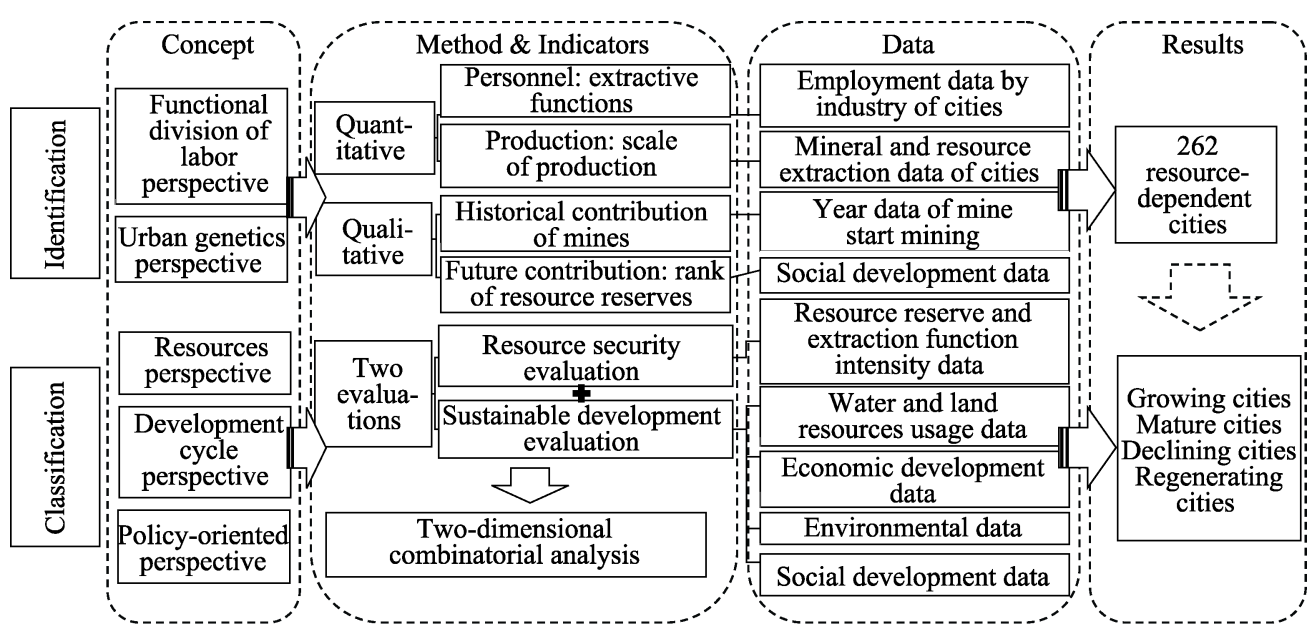

Figure 1 Identification and classification framework for resource-dependent cities

Based on the division of national administrative units, this study first identified China's 334 prefectural administrative units, as well as its 2,851 county-level administrative units for cases where prefectural administrative units fail to meet the standard, which were combined to identify the specific scopes of China's resource-dependent cities. Data was sourced from China City Statistical Yearbook, with survey data from the National Development and Reform Commission and the National Bureau of Statistics.

\subsection{Extraction function intensity}

The intensity of extraction functions is an indicator for measuring the level of employment in extractive industries in resource-dependent cities. The Nelson method is commonly used to measure this. The Nelson method is a method commonly used to measure the intensity of a function in urban function classification studies. The method essentially uses standard deviation to measure the deviation rate of various urban functions. The calculation method is as follows:

$$
s_{D}=\sqrt{\frac{\sum_{\mathrm{i}=1}^{n} d_{i}^{2}}{N}}
$$

where $d_{i}$ is the percentage of a city's employed population employed in industry $i$ minus the mean value of the percentages of employed populations in cities throughout China that are employed in the same industry. Since the focus of this paper is resource-dependent cities, industry $i$ refers only to extractive industries. $N$ is the number of cities. The mean $(M)$ and standard deviation $\left(S_{D}\right)$ of the percentage of employed people working in extractive industries were calculated for each city. One standard deviation above the mean $\left(M+S_{D}\right)$ was used as the minimum intensity standard for measuring if cities have specialized functions. Any value a few standard deviations above the mean indicates strong specialization. Some studies have argued that one standard deviation above the mean in the Nelson method is too high. From the perspective of analysis on China's urban data, the standard of one standard deviation above the mean is indeed too high. The mean proportion of people employed in extractive industries in national prefecture-level cities is $4.8 \%$; whereas, the standard deviation is $8.7 \%$. 
Even if China's cities are measured using the criterion of 0.5 standard deviations above the mean, some cities recognized by academics as being resource-dependent, such as Handan (0.71), Pingxiang (0.78) and Jiaozuo (0.72), do not meet the standard.

Using the standard of between 0.3 and 0.5 standard deviations above the mean to identify cities in China, it is discovered that the following cities, which are widely recognized as having resource-dependent features, do not fall between the two thresholds: Taiyuan, Wienan, Laiwu, Pingxiang, Chenzhou, Jiaozuo, Chifeng, Handan and Hulunbuir. However, cities with standard deviations of below 0.3, such as Leshan and Shangqiu, are generally recognized as not having resource-dependent features. As a result, this article considers an accurate threshold value for identifying resource-dependent cities in China to be those that are more than 0.3 standard deviations above the mean (Figure 2).

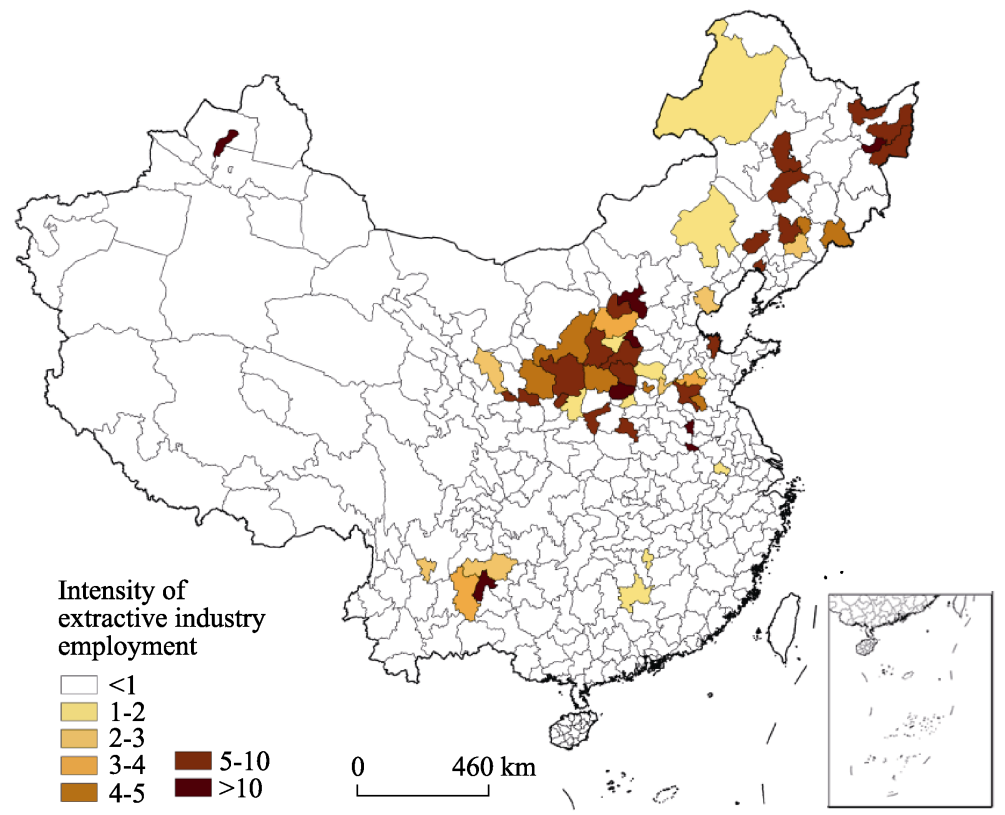

Figure 2 Intensity of extractive industry employment in China

\subsection{Output coefficient}

The output coefficient measures the external role of resource or mineral products of cities. It essentially measures the difference between resource products as a proportion of a city's output and resource products as a proportion of a city's economy. The calculation method is as follows:

$$
C_{i}=\frac{m_{i} / M}{g_{i} / G}
$$

here $C_{i}$ is the output coefficient for resource products of city $i, m$ is the output volume of resource products of city $i$ for the current year, $M$ is the national output value for the corresponding resource product, $g_{i}$ is the gross metropolitan product (GMP) of city $i$ for the current year, and $G$ is China's gross domestic product (GDP) for the current year. When $C_{i}$ is greater than one, the resource products of city $i$ are considered to have external supply capabilities, and the basic functions of urban extractive industries are considered to be significant, 
meaning the city can be identified as a resource-dependent city (Figure 3).

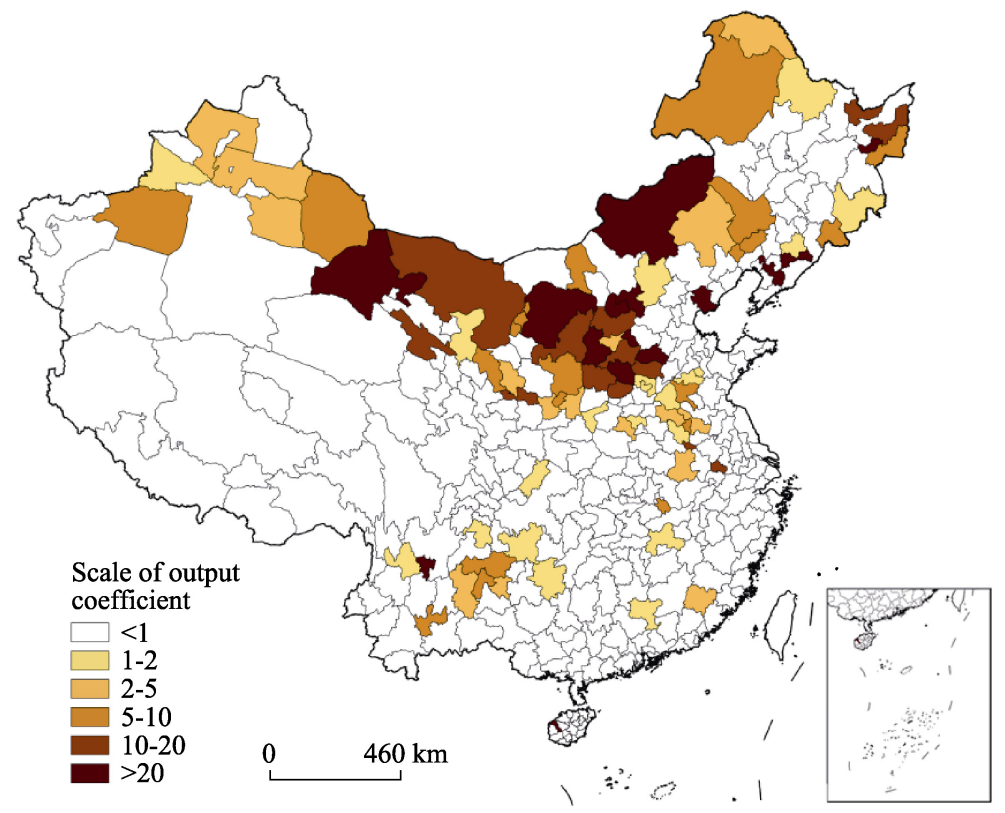

Figure 3 Resource output coefficients of cities in China

\subsection{Level of resource contribution}

The industrial economic structures of Chinese cities are generally characterized by low levels of specialization, with many cities having multiple developed sectors. As a result, some cities with relatively obvious resource-dependent features cannot be screened out using quantitative indicators. This requires the supplementation of qualitative characteristics. The city of Jinchang, for example, is known as the "nickel capital" of China for having the second largest nickel reserves in the world and the largest in China, but its extraction function intensity value is -1.75 , far below the threshold value. The reason for this is not that the city's extraction functions are weak, but that its overall development is strong as a result of being driven on by its mining industry, which reduces the proportion of resource-related activities.

Level of resource contribution is a qualitative measure that mainly measures contributions in two areas: significant contributions to national resource requirements over a long period of history and significant contributions to national resource requirements in the foreseeable future. From the perspective of urban genetics, thriving resource exploitation or the presence of large and medium-sized resource enterprises or mines within cities can serve as qualitative indicators of historical contributions (Table 1), while world-class or nationally significant reserves of mineral resources can serve as qualitative indicators of future contributions (Table 2). Only one of these conditions needs to be met. As such, this study looked at China's famous historical mines and the cities they are located in and included those cities on the list of resource-dependent cities. We also researched and drew up a list of cities with known reserves of mineral resources that are globally or nationally significant as cities that will make significant contributions in the future and included them on the list of resource-dependent cities as well. 
Table 1 China's historically significant mines and their cities

\begin{tabular}{|c|c|c|c|}
\hline City & Mine and year extraction began & City & Mine and year extraction began \\
\hline Hegang & Hegang Coal Mine (1917) & Datong & Datong Coal Mine (1907) \\
\hline Jixi & Jixi Coal Mine (1925) & Tangshan & Kailuan Coal Mine (1881) \\
\hline Liaoyuan & Xi'an Coal Mine (1912) & Hebi & Hebi Coal Mine (1912) \\
\hline Anshan & Qidashan Iron Mine (1918) & Jiaozuo & Jiaozuo Coal Mine (1898) \\
\hline Benxi & Benxihu Iron Mine (1904) & Yima* $^{*}$ & Yima Coal Mine (1919) \\
\hline Fushun & Fushun Coal Mine (1901) & Zaozhuang & Zaozhuang Coal Mine (1818) \\
\hline Fuxin & Fuxin Coal Mine (1936) & Huainan & Huainan Coal Mine (1911) \\
\hline Beipiao* & Beipiao Coal Mine (1921) & Pingxiang & Pingxiang Coal Mine (1898) \\
\hline Ruichang & Tongling Copper Mine (Shang Dynasty) & Zigong & salt mining (Ming Dynasty) \\
\hline Hancheng ${ }^{*}$ & Hancheng Coal Mine (1931) & Yumen ${ }^{*}$ & Yumen Oilfield (1939) \\
\hline Shizuishan & Shizuishan Coal Mine (1949) & Gejiu $^{*}$ & Gejiu Tin Mine (1886) \\
\hline Lengshuijiang $^{*}$ & Xikuangshan Antimony and Coal Mine (1860) & Jingdezhen & Yetao $(1,800+$ years $)$ \\
\hline Tongling & Tongguanshan Copper Mine (Shang Dynasty) & Daye & Daye Iron Mine (1890) \\
\hline Tongren & Wanshan Mercury Mine (Tang Dynasty) & Heshan $^{*}$ & Heshan Coal Mine (1919) \\
\hline
\end{tabular}

Note: * indicates a county-level city. The rest are prefecture-level cities.

\subsection{Identification results}

The indicator-based identification of resource-dependent cities was conducted using an aggregated indices method, which means that cities that met any one of the three indicators (extraction function intensity, output coefficient or level of resource contribution) were deemed to be resource-dependent cities. Using this method, 262 resource-dependent cities (or regions) were identified from cities across China (Figure 4), including 128 prefecture-level cities (prefecture-level divisions, autonomous prefectures, leagues, etc.), 62 county-level cities, 58 counties (autonomous counties, banners, etc.) and 14 municipal districts. Together they account for 3.8 million $\mathrm{km}^{2}$ (40\%) of China's total land area and contain 440 million people, $33 \%$ of China's total population.

Of the 128 prefecture-level cities (prefecture-level divisions, autonomous prefectures, leagues, etc.) identified as resource-dependent cities, the densest concentration is in China's western region (50 cities or $39.1 \%$ ), followed by the central region ( 37 cities, $28.9 \%$ ), the northeastern region (21 cities, 16.4\%) and the eastern region (20 cities, 15.6\%). Of the 62 county-level cities identified as resource-dependent cities, the densest concentration occurs in the central region (43.6\%), followed by the western region $(25.8 \%)$, the eastern region $(16.1 \%)$ and the northeastern region (14.5\%). Of the 58 resource-dependent counties, over half (31 counties, 53.5\%) are in the western region, $24.1 \%$ are in the eastern region, $17.2 \%$ are in the central region and $5.2 \%$ are in the northeastern region. There are only a few (14) resource-dependent municipal districts, and they are mainly found in the eastern and western regions.

\section{Classification of resource-dependent cities}

\subsection{Classification framework}

Resource-dependent cities are affected by a "resource curse", as urban development is ham 
Table 2 List of places with significant mineral resource reserves

\begin{tabular}{|c|c|c|c|c|c|c|c|}
\hline \multirow[b]{2}{*}{ Place } & \multirow[b]{2}{*}{ Resource type } & \multicolumn{2}{|c|}{ Location of reserves } & \multirow[b]{2}{*}{ Place } & \multirow{2}{*}{$\begin{array}{l}\text { Resource } \\
\text { type }\end{array}$} & \multicolumn{2}{|c|}{ Location of reserves } \\
\hline & & $\begin{array}{c}\text { Global } \\
\text { significance }\end{array}$ & $\begin{array}{c}\text { National } \\
\text { significance }\end{array}$ & & & $\begin{array}{c}\text { Global } \\
\text { significance }\end{array}$ & $\begin{array}{c}\text { National } \\
\text { significance }\end{array}$ \\
\hline Ningwu County & Bauxite & & $\sqrt{ }$ & $\begin{array}{l}\text { Yingcheng } \\
\text { City }\end{array}$ & Gypsum & & $\sqrt{ }$ \\
\hline Yuanqu County & Copper & & $\sqrt{ }$ & $\begin{array}{l}\text { Chenzhou } \\
\text { City }\end{array}$ & $\begin{array}{l}\text { Tungsten, } \\
\text { Bismuth, } \\
\text { Molybdenum, } \\
\text { Tin, Zinc }\end{array}$ & & $\sqrt{ }$ \\
\hline Baotou City & Rare earth & $\sqrt{ }$ & & $\begin{array}{l}\text { Changning } \\
\text { City }\end{array}$ & $\begin{array}{l}\text { Lead, Zinc, } \\
\text { Tin, Boron, } \\
\text { Wollastonite }\end{array}$ & & $\sqrt{ }$ \\
\hline Xilinhot City & Germanium & & $\sqrt{ }$ & Hechi City & Indium & $\sqrt{ }$ & \\
\hline Anshan City & Iron & & $\sqrt{ }$ & $\begin{array}{l}\text { Pinggui } \\
\text { District }\end{array}$ & Calcium & & $\sqrt{ }$ \\
\hline $\begin{array}{l}\text { Yangjiazhangzi } \\
\text { District }\end{array}$ & Molybdenum & & $\sqrt{ }$ & Cenxi City & Granite & & $\sqrt{ }$ \\
\hline $\begin{array}{l}\text { Xiuyan Manchu } \\
\text { Autonomous } \\
\text { County }\end{array}$ & Magnestite, Jade & & $\sqrt{ }$ & $\begin{array}{l}\text { Changjiang } \\
\text { County }\end{array}$ & Iron ore & & $\sqrt{ }$ \\
\hline $\begin{array}{l}\text { Kuandian } \\
\text { County }\end{array}$ & Boron & & $\sqrt{ }$ & Ya'an City & Asbestos & & $\sqrt{ }$ \\
\hline Haicheng City & Talc & $\sqrt{ }$ & & $\begin{array}{l}\text { Mianzhu } \\
\text { City }\end{array}$ & Phosphorus & & $\sqrt{ }$ \\
\hline Fengcheng City & Boron, Andalusite & & $\sqrt{ }$ & $\begin{array}{l}\text { Kaiyang } \\
\text { County }\end{array}$ & Phosphorus & & $\sqrt{ }$ \\
\hline Linjiang City & $\begin{array}{l}\text { Diatomite, Dolo- } \\
\text { mite }\end{array}$ & & $\sqrt{ }$ & $\begin{array}{l}\text { Qingzhen } \\
\text { City }\end{array}$ & Bauxite & & $\sqrt{ }$ \\
\hline $\begin{array}{l}\text { Daxinganling } \\
\text { Region }\end{array}$ & Lumber & & $\sqrt{ }$ & $\begin{array}{l}\text { Lanping } \\
\text { County }\end{array}$ & Lead-zinc ore & $\sqrt{ }$ & \\
\hline Xunke County & Pearlite & & $\sqrt{ }$ & $\begin{array}{l}\text { Maguan } \\
\text { County }\end{array}$ & Indium, Tin & & $\sqrt{ }$ \\
\hline Longyan Iron & $\begin{array}{l}\text { Iron, Copper, } \\
\text { Kaolinite }\end{array}$ & & $\sqrt{ }$ & $\begin{array}{l}\text { Qusong } \\
\text { County }\end{array}$ & Chromium & & $\sqrt{ }$ \\
\hline Nanping City & Niobium-tantalum & $\sqrt{ }$ & & $\begin{array}{l}\text { Weinan } \\
\text { City }\end{array}$ & $\begin{array}{l}\text { Molybdenum, } \\
\text { Lead, Cop- } \\
\text { per, Niobium, } \\
\text { Selenium, } \\
\text { Iron, Bauxite, } \\
\text { Rhenium }\end{array}$ & & $\sqrt{ }$ \\
\hline Ganzhou City & Tungsten & $\sqrt{ }$ & & $\begin{array}{l}\text { Tongguan } \\
\text { County }\end{array}$ & Gold & & $\sqrt{ }$ \\
\hline Dexing City & Copper & & $\sqrt{ }$ & $\begin{array}{l}\text { Golmud } \\
\text { City }\end{array}$ & $\begin{array}{l}\text { Potassium, } \\
\text { Magnesium, } \\
\text { Lithium, Bo- } \\
\text { ron, Bromine, } \\
\text { Iodine, Ru- } \\
\text { bidium }\end{array}$ & & $\sqrt{ }$ \\
\hline Pingdu City & Graphite & & $\sqrt{ }$ & $\begin{array}{l}\text { Fuyun } \\
\text { County }\end{array}$ & $\begin{array}{l}\text { Non-ferrous } \\
\text { metal }\end{array}$ & & $\sqrt{ }$ \\
\hline Xingtai City & Kyanite & & $\sqrt{ }$ & $\begin{array}{l}\text { Ruoqiang } \\
\text { County }\end{array}$ & $\begin{array}{l}\text { Potassium } \\
\text { Chloride }\end{array}$ & & $\sqrt{ }$ \\
\hline $\begin{array}{l}\text { Luanchuan } \\
\text { County }\end{array}$ & $\begin{array}{l}\text { Molybdenum, } \\
\text { Tungsten }\end{array}$ & & $\sqrt{ }$ & Hami City & $\begin{array}{l}\text { Nickel, Cop- } \\
\text { per }\end{array}$ & & $\sqrt{ }$ \\
\hline Zhongxiang City & Phosphorus & & $\sqrt{ }$ & & & & \\
\hline
\end{tabular}




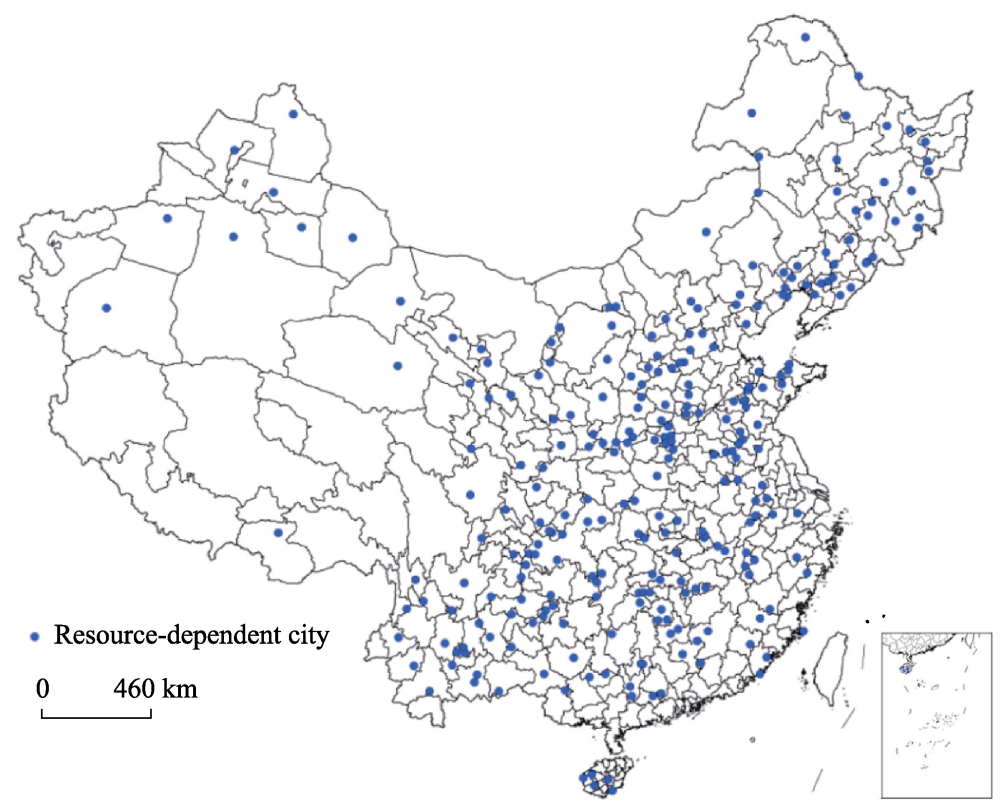

Figure 4 Distribution of resource-dependent cities

pered by factors such as accelerated environmental deterioration and waning economic momentum, making them significantly more vulnerable than other cities (Fang and Wang, 2015). These problem-oriented characteristics make it important to classify cities for the sake of policy guidance. As such, resource security and urban development issues should dominate the classification of resource-dependent cities for policy guidance. The relationship between these two things is used to comprehensively classify cities as follows. Cities with high levels of resource security and few development issues are in a period of growth and are referred to here as growing cities; cities with declining resource security and accumulating development issues are referred to as mature cities; cities whose resources are nearly depleted and with relatively many development issues are referred to as declining cities; and cities with practically depleted resources and extremely low resource security but with good transformation and development prospects and that are addressing their various problems are referred to as regenerating cities.

There is a direct correlation between the number of development issues and strength of sustainable development in resource-dependent cities. To facilitate better and more intuitive understanding, the negative indicator system of accumulated development issues was converted into the positive indicator system of urban sustainable development capacity. As such, the classification of resource-dependent cities into the aforementioned four categories was based on evaluations of their resource security and capacity for sustainable development. First, values for these two indicators were calculated separately using different index systems. Then, a cluster analysis method was used to perform two-dimensional combinatorial analysis on the two values and divide cities into the four categories (Figure 5).

Using the above classification framework, the 262 Chinese cities identified as resource-dependent cities were classified as either growing cities, mature cities, declining cities or regenerating cities. In total, 31 are classified as growing cities, including 20 prefecture-level administrative districts, seven county-level cities and four counties (autonomous 


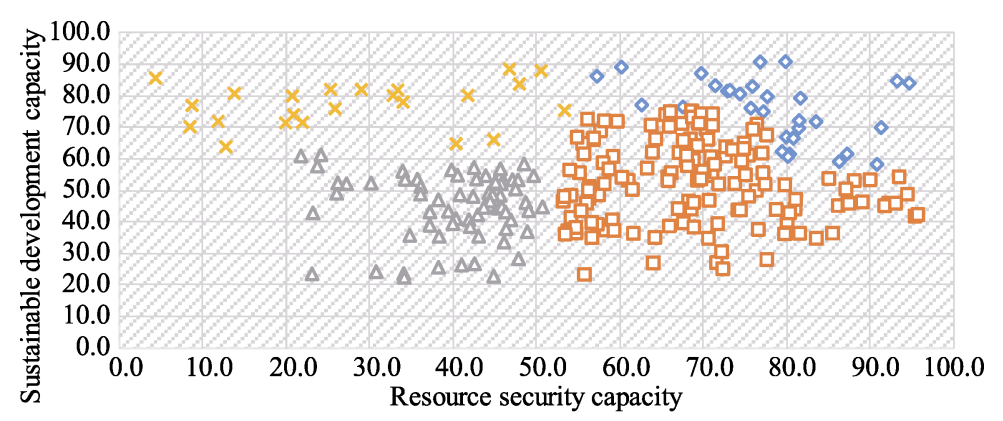

$\diamond$ Growing city $\square$ Mature city $\Delta$ Declining city $\times$ Regenerating city

Figure 5 Two-dimensional combinations of the 262 resource-dependent cities

counties and autonomous banners); 141 as mature cities, including 66 prefecture-level administrative districts, 29 county-level cities and 46 counties (autonomous counties and autonomous banners); 67 as declining cities, including 26 prefecture-level administrative districts, 22 county-level cities, and five counties (autonomous counties and autonomous banners); and 23 as regenerating cities, including 16 prefecture-level administrative districts, four county-level cities and three counties (autonomous counties and autonomous banners) (Table 3).

Table 3 Administrative status of resource-dependent cities

\begin{tabular}{|c|c|c|c|c|c|c|c|c|}
\hline \multirow{2}{*}{ City category } & \multicolumn{2}{|c|}{ Pref-level city } & \multicolumn{2}{|c|}{ County-level city } & \multicolumn{2}{|c|}{ County } & \multicolumn{2}{|c|}{ Municipal district } \\
\hline & No. & Ratio & No. & Ratio & No. & Ratio & No. & Ratio \\
\hline Growing & 20 & $15.6 \%$ & 7 & $11.3 \%$ & 4 & $6.9 \%$ & 0 & $0.0 \%$ \\
\hline Mature & 66 & $51.6 \%$ & 29 & $46.8 \%$ & 46 & $79.3 \%$ & 0 & $0.0 \%$ \\
\hline Declining & 26 & $20.3 \%$ & 22 & $35.5 \%$ & 5 & $8.6 \%$ & 14 & $100.0 \%$ \\
\hline Regenerating & 16 & $12.5 \%$ & 4 & $6.5 \%$ & 3 & $5.2 \%$ & 0 & $0.0 \%$ \\
\hline Total & 128 & $100.0 \%$ & 62 & $100.0 \%$ & 58 & $100.0 \%$ & 14 & $100.0 \%$ \\
\hline
\end{tabular}

\subsection{Differences between the four categories of cities}

In terms of resource security and sustainable development, growing cities have the following characteristics: first is strong resource security as they are in the stage of increasing resource exploitation, with large reserves and many years to exploit their resource(s); second is rapid economic growth, with extractive industries driving exponential growth in the wider urban economy. However, growing cities generally also have to deal with significant issues including irregulated resource extraction and unbalanced economic development.

The following are the characteristics of mature cities: first, resource exploitation has peaked and been stable for a number of years, so there is a mature system of resource extraction, transportation and processing; second, urban development is relatively mature and levels of various types of urban construction are relatively high. Nevertheless, having extracted resources for a relatively long time, mature resource-dependent cities suffer from severe environmental damage and usually many conflicts over the distribution of benefits arising from land acquisitions and clearing for the sake of resource exploitation.

Declining cities can be characterized as follows: first, resources are reaching depletion and some mines have been closed; second, internal drivers of urban development are weak, and economic, social and environmental developments are waning. Affected by the 


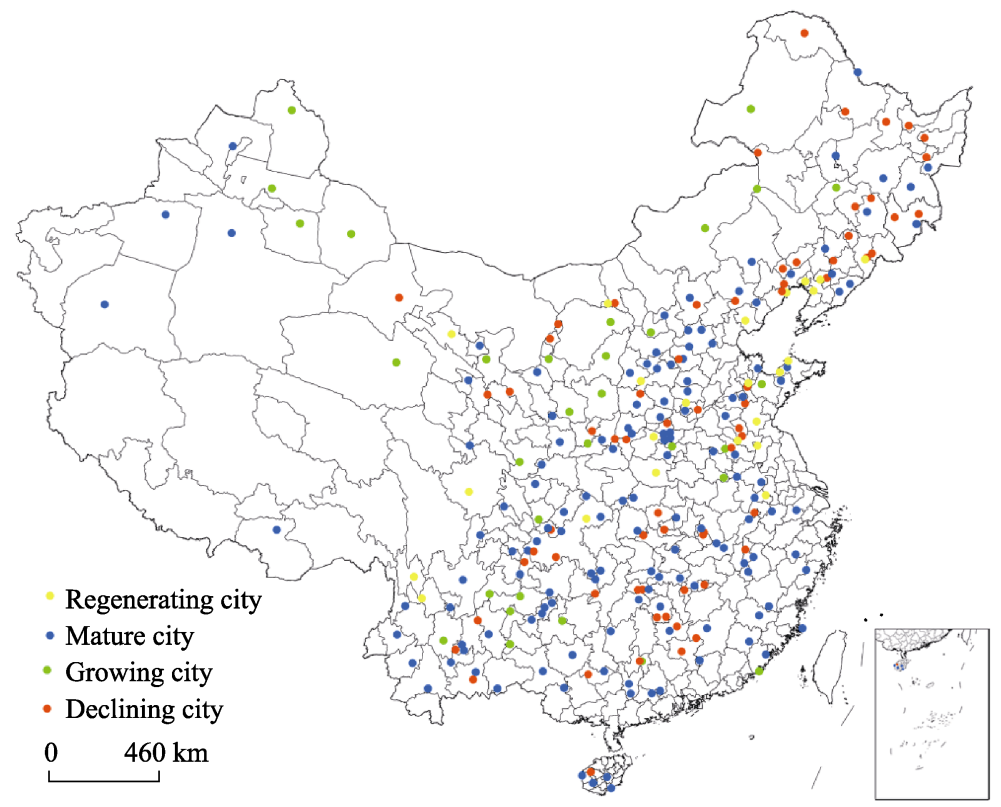

Figure 6 Distribution of the four categories of resource-dependent cities

slowdown in resource-based economic development, many declining cities suffer from deteriorating living conditions for miners and high unemployment and they are plagued by historical legacies such as slums, social security debt and geological disasters. The recovery and treatment rate of the geological environment in $75 \%$ of declining resource-dependent cities remains below $50 \%$, and the recovery and treatment rate is below $10 \%$ in the other quarter of cities. There is still $5,800 \mathrm{~km}^{2}$ of land suffering from subsidence as a result of underground coal-mining, along with many other outstanding historical issues affecting declining cities.

Regenerating cities generally have the following features: first, they have a long history of resource exploitation activities, though the vast majority of activities have now ceased; second, urban development is no longer as dependent on resources, with the economy and society moving onto a healthy development track. Regenerating cities are undergoing a change in their industrial structure as non-resource industries become the new mainstays of urban economic development and steps are taken to resolve historical economic, social and environmental issues caused by resource exploitation (Table 4).

Several indicators were selected to analyze the differences between the four categories of resource-dependent cities from the perspectives of economic development, location, industrial division of labor, social development and environmental protection (Table 5), including the following: the ratio of mining to manufacturing (i.e. the ratio of workers in extractive industries to workers in manufacturing industries) is used to determine the extent of urban resource-related industry chains; a management function specialization coefficient (i.e. the ratio of management to production personnel) is used to determine the management-production function link in the process of industrial upgrading in resource-dependent cities; a diversity coefficient was used to determine the diversity level of the industrial development of cities; the degree of industrial concentration (i.e. the proportion of urban industrial output value 
Table 4 Characteristics, problems and transformations of the four categories of resource-dependent cities

\begin{tabular}{|c|c|c|c|}
\hline City category & Main characteristics & Main problems & Transformations \\
\hline Growing & $\begin{array}{l}\text { Large reserves, large-scale } \\
\text { exploitation, rapid economic } \\
\text { growth }\end{array}$ & $\begin{array}{l}\text { Unregulated resource extraction and } \\
\text { unbalanced economic development }\end{array}$ & $\begin{array}{l}\text { Regulating extraction, man- } \\
\text { aging development, expand- } \\
\text { ing resource industry chain }\end{array}$ \\
\hline Mature & $\begin{array}{l}\text { Large, stable resource ex- } \\
\text { ploitation, mature system of } \\
\text { resource extraction, trans- } \\
\text { portation and processing }\end{array}$ & $\begin{array}{l}\text { Severe environmental damage and } \\
\text { multiple conflicts over distribution } \\
\text { of benefits from resource exploita- } \\
\text { tion }\end{array}$ & $\begin{array}{l}\text { Greater environmental gov- } \\
\text { ernance and increased social } \\
\text { undertakings }\end{array}$ \\
\hline Declining & $\begin{array}{l}\text { Resources reaching depletion } \\
\text { and weak internal drivers of } \\
\text { development }\end{array}$ & $\begin{array}{l}\text { Deteriorating living conditions for } \\
\text { miners and high unemployment, } \\
\text { plagued by historical legacies such } \\
\text { as slums, social security debt and } \\
\text { geological disasters }\end{array}$ & $\begin{array}{l}\text { Stimulating re-employment, } \\
\text { transforming slums, support- } \\
\text { ing social security, recovery } \\
\text { and treatment of mining areas }\end{array}$ \\
\hline Regenerating & $\begin{array}{l}\text { Vast majority of mining ac- } \\
\text { tivities have ceased and de- } \\
\text { velopment no longer de- } \\
\text { pendent on resources }\end{array}$ & $\begin{array}{l}\text { Limited innovative development } \\
\text { and incomplete development of } \\
\text { urban functions }\end{array}$ & $\begin{array}{l}\text { Improving quality of eco- } \\
\text { nomic development, in- } \\
\text { creased levels of openness } \\
\text { and innovation, improved } \\
\text { urban functions }\end{array}$ \\
\hline
\end{tabular}

Table 5 Comparison of indicators for four categories of resource-dependent cities

\begin{tabular}{llcccc}
\hline \multicolumn{1}{c}{ Type } & \multicolumn{1}{c}{ Indicator } & Growing & Mature & Declining & Regenerating \\
\hline General & Average GDP (100 million yuan) & 1402 & 1313 & 844 & 2590 \\
& Public financial pressure coefficient & 2.58 & 2.58 & 2.44 & 1.76 \\
& Average distance to the nearest provincial & 233 & 171 & 184 & 199 \\
& capital (km) & & & \\
Industrial & Management function specialization coefficient & 0.55 & 0.61 & 0.38 & 0.64 \\
& Mining and manufacturing ratio & 1.71 & 0.86 & 1.23 & 0.34 \\
& Diversity coefficient & 3.00 & 3.82 & 4.10 & 5.83 \\
& Industrial agglomeration & $32.76 \%$ & $38.05 \%$ & $54.24 \%$ & $49.44 \%$ \\
Social & Average per capita road area (m ${ }^{2}$ ) & 9.92 & 12.17 & 11.79 & 12.74 \\
& Logistical connectivity & 7.05 & 16.30 & 10.54 & 8.40 \\
Environmental & Sulfur dioxide emissions (tons/100 million yuan) & 45.4 & 41.3 & 51.3 & 32.6 \\
& Industrial wastewater discharge (tons/100 & 2.42 & 3.69 & 4.71 & 2.70 \\
\hline
\end{tabular}

Data source: China City Statistical Yearbook 2016

accounted for by municipal districts) is used to determine the level of agglomeration of urban industries in urban areas; and logistical transportation intensity (i.e. the total volume of passenger and freight transport per unit of GDP) is used to determine the degree of connectivity between a city's passenger and freight transport.

The management function specialization coefficient is based on the method of Bade et al. (2004), whereby leasing and business services employees are considered management personnel and personnel involved in extractive industries, manufacturing, and the production and supply of electricity, gas and water are considered production personnel.

The diversity index draws on the Gini specialization coefficient used by Duranton and Puga (2001, 2004, 2005), which is expressed as an inverse proportion of the specialization coefficient. The formula is as follows: 


$$
D D_{i}=\frac{1}{\sum_{j}\left|D_{i j}-D_{j}\right|}
$$

where $D_{i j}$ denotes the proportion of people employed in industry $j$ of city $i, D$ is the proportion of people employed nationwide in industry $j$, and the value range of $D D_{i}$ is $[1,+]$. The larger the value, the more diverse a city's industry.

Looking at overall development and location indicators, regenerating cities have the largest economies and declining cities have the smallest, with a nearly threefold difference in size between them. Growing cities have the highest economic growth rate. Between 2005 and 2015, the average growth rate of growing cities was $13.29 \%$, much higher than the national average for resource-dependent cities of $9.58 \%$. Resource-dependent cities other than regenerating cities have a higher coefficient of public financial pressure than the national average of 1.69. Taking distance from a provincial capital as an example, mature and declining cities are in relatively close proximity, below the average of $198 \mathrm{~km}$ for cities nationwide, whereas growing cities tend to be relatively far from provincial capitals, $62 \mathrm{~km}$ further away on average than mature cities. This supports the theory that distance from economic and social centers affects resource exploitation activities.

According to the results from measuring the management function specialization coefficient, regenerating cities and mature cities have more obvious management functions, but declining cities are relatively weak in this regard. This shows that, compared with the proportion of production personnel, the decline of an urban economy significantly affects the number of management personnel.

Mature resource-dependent cities have relatively well-established systems of resource-related industries as well as extensive processing industry chains. This is also reflected by the ratio of extractive to manufacturing industries. Excluding regenerating cities, only mature cities had a ratio of less than 1 . Both growing and declining cities have much larger extractive industry employment than manufacturing industry employment. Despite a general decline in the proportion of the national working population employed in extractive industries in China between 2005 and 2015, the proportion of people employed in those industries in growing resource-dependent cities is continuing to increase.

Changing the diversity of a city is a gradual process. Resource-dependent cities can be listed from least diverse to most diverse according to the diversity coefficients as follows: growing cities, mature cities, declining cities, generating cities. This is inverse to dependence on the resource-related economy. The dispersed nature of resource extraction activities means that growing cities and mature cities have comparatively low levels, and declining and regenerating cities have relatively high levels, of industrial agglomeration.

In terms of social development indicators, mature cities performed best, with higher per capita road area and logistical connectivity than other city categories, with growing cities performing particularly badly. This confirms that growing cities tend to have unbalanced economic and social development.

Finally, looking at environmental indicators, declining cities have the highest levels of wastewater discharge and sulfur dioxide emissions, though growing cities have relatively high sulfur dioxide emissions due to the prevalence of coal-mining, coal-fired power gen- 
eration and other coal-based industries. Meanwhile, regenerating cities have relatively low levels of wastewater discharge and sulfur dioxide emissions.

\section{Conclusion and discussion}

This problem-oriented study constructed a system for recognizing and classifying resource-dependent cities for the sake of policy implementation. Its methodology differs from traditional studies that use single indicators or quantitative indicators to identify such cities or that use urban lifecycle or main resources to classify them, instead using a combination of quantitative and qualitative methods, thereby improving identification accuracy. This system also focuses on measuring the external contributions of mineral products, but cities with relatively large volumes of mineral processing, such as cities with both iron ore mining and steel production, score poorly on the indicators of strength of extraction functions and output coefficient. Identifying such cities more accurately is key to optimizing the identification system.

As China's economic and social development deepens, the role resource-dependent cities play in supporting national development will become increasingly apparent, the conflict between rigid expansion in demand for national resources and diverse development in resource-dependent cities will intensify, and development issues in resource-dependent cities will become more severe. This is especially true as resource extraction continues. Resource-dependent cities currently classified as growing and mature will move into the next stage of their development, meaning they will face more acute development problems. It is likely that a deeper analysis of development problems of resource-dependent cities from economic, social, environmental and other perspectives, as well as refinement of the problem-oriented classification method for resource-dependent cities, will become important areas of study in the future. Targeted research of different regions and different categories of resource-dependent cities constitute important approaches for furthering our understanding of different types of resource-dependent cities.

\section{References}

Bade F J, Laaser C F, Soltwedel R, 2004. Urban specialization in the internet age: Empirical findings for Germany. Kiel Working Paper, No.1215.

Duranton G, Puga D, 2001. Nursery cities: Urban diversity, process innovation, and the life cycle of products. American Economic Review, 91(5): 1454-1477.

Duranton G, Puga D, 2003. Micro-foundations of urban agglomeration economies. Social Science Electronic Publishing, 4(4): 2063-2117.

Duranton G, Puga D, 2005. From sectoral to functional urban specialization. Journal of Urban Economics, 57(2): 343-370.

Fan Jie, 1993. A study on the industrial structure transformation of coal-mine cities in China. Acta Geographica Sinica, 48(3): 218-225. (in Chinese)

Fang Chuanglin, Wang Yan, 2015. A comprehensive assessment of urban vulnerability and its spatial differentiation in China. Acta Geographica Sinica, 70(2): 234-247. (in Chinese)

Han Fengqin, Wan Shouqiong, 2014. Classified to promote the sustainable development of resource-based cities in China. Review of Economic Research, (54): 5-11. (in Chinese) 
Harris C D, 1943. A functional classification of cities in the United States. Geographical Review, 33(1): 86-99.

Hu Kui, 2001. The basic problems of China's mining cities. Resources \& Industries, 3(5): 1-7. (in Chinese)

Li Wenyan, 1978. Industrial development and urban planning in coal mine cities. Acta Geographica Sinica, 33(1): 63-79. (in Chinese)

Liu Yungang, 2006. The reconsideration of the method to define Chinese resource-based cities. Economic Geography, 26(6): 940-944. (in Chinese)

Liu Yungang, 2009. The functional classification and the characteristics of functional transition of Chinese resource-based cities. Geographical Research, 28(1): 153-160. (in Chinese)

Ma Qingyu, 1986. Development and Layout of Industrial and Mining Cities. Regional Studies on Urban and Industrial Distribution. Beijing: Science Press. (in Chinese)

Macroeconomic Research Group of National Planning Commission (MRGNPC), 2002. The definition and classification of resource-based cities in China. Macroeconomics, (11): 37-39. (in Chinese)

Nelson H J, 1955. A service classification of American cities. Economic Geography, 31(3): 189-210.

Shen Lei, Cheng Jing, 1999. A preliminary discussion on the mechanism of mining cities for sustainable development. Resources Science, 21(1): 44-50. (in Chinese)

Wang Qingyun, 2003. Study on the Economic Transformation of Resource-Based Cities. Beijing: China Economic Publishing House. (in Chinese)

Wu Chunyou, Ye Ying, 2000. Study of the issue of transformation of the industry for the resource-typed cities. Journal of Dalian University of Technology (Social Sciences), 21(3): 6-9. (in Chinese)

Xiao Jingsong, Li Hongjun, 2009. A study on definitions and classification of resource-based cities in China. Sino-Global Energy, 14(11): 15-20. (in Chinese)

Yu Jicong, Liu Yuexiang, 2009. Study on the Definition of Mining City and its Sustainable Development Ability. Beijing: Geological Publishing House. (in Chinese)

Zhang Jianhua, Wang Gaoshang, 2003. Mining dependence and quantitative classification of China mining cities. Resources \& Industries, 5(6): 85-89. (in Chinese)

Zhang Wenzhong, Yu Jianhui, Wang Dai et al., 2014. Research on the Sustainable Development of Resource-based Cities in China. Beijing: Science Press. (in Chinese)

Zhang Yicheng, 1999. The present situation and sustainable development countermeasures of mining cities in China. Journal of China University of Mining and Technology (Social Science), (1): 75-78. (in Chinese)

Zhao Kangie, Zhao Yujuan, 2011. The definition and classification of resource-based cities: A case study of Shanxi province. China Urban Economy, (30): 40-43. (in Chinese)

Zhao Yukong, 1995. China's Mining City: Structural Adjustment and Sustainable Development. Changchun: Jilin Science and Technology Press. (in Chinese)

Zhou Changqing, 1994. On the attributes and structures of resources-model cities and their coordinating development. Reform of Economic System, (5): 23-30. (in Chinese)

Zhou Yixing, Roy Bradshaw, 1988. The classification of industrial function of Chinese cities (including attached counties): Theory, method and results. Acta Geographica Sinica, 43(4): 287-298. (in Chinese)

Zhou Yixing, Sun Zexing, 1997. Rediscussion on China's urban function classification. Geographical Research, 16(1): 11-22. (in Chinese) 